\title{
Management of Colloid Cyst of Third Ventricle
}

\section{Ü̧̧üncü Ventrikül Kolloid Kistinin Yönetimi}

\author{
Yad Ram YADAV ${ }^{1}$, Nishtha YADAV ${ }^{2}$, Vijay PARIHAR ${ }^{1}$, Yatin KHER ${ }^{1}$, Shailendra RATRE \\ ${ }^{1}$ NSCB Medical College Jabalpur MP India, Department of Neurosurgery, Jabalpur, India \\ ${ }^{2}$ All India Institute of Medical Science, Department of Radio Diagnosis and Imaging, New Delhi, India
}

Corresponding Author: Yad Ram YADAV / E-mail: yadramyr@yahoo.com

\begin{abstract}
Colloid cysts are usually located in third ventricle and are believed to be derived from either primitive neuroepithelium or endoderm. Patients may remain asymptomatic for long time while some can present with paroxysmal headache, gait disturbance, nausea, vomiting, behavioral changes, weaknesses of lower limbs, impaired memory, new learning disability and sudden death. Computed tomography usually reveals a well-defined round or oval nonenhancing lesion. Although magnetic resonance imaging (MRI) signal intensity of colloid cysts is variable, the most common appearance is hyperintensity in T1-weighted sequences and iso to hypointensity in T2-weighted sequences. Observation, stereotactic aspiration, microscopic or endoscopic approaches and shunt surgery are various management options. Transcallosal and transcortical microscopic (with or without tubular retractor) approaches are mainly useful in normal-sized and dilated ventricles respectively. Endoscopic technique is an effective alternative to microsurgical technique but total resection and long-term recurrence remains a concern. Utilization of two instruments, the bi port technique and tubular retractor can be helpful in selected patients to overcome limitations. Although total excision should be aimed, subtotal excision and coagulation of residual cyst wall usually results in good long-term results without any growth of remnant wall. Conversion to an open procedure may be required in some patients.
\end{abstract}

KEYWORDS: Central nervous system cyst, Central nervous system neoplasm, Colloid cyst, Nervous system diseases, Third ventricle

\section{öz}

Kolloid kistler genellikle üçüncü ventrikülde bulunur ve primitif nöroepitel veya endodermden köken aldıklarına inanılmaktadır. Hastalar uzun süre belirtisiz kalabilirler veya durum paroksismal baş ağrısı, yürüme bozukluğu, bulantı, kusma, davranış değişiklikleri, alt ekstremitelerde kuvvetsizlik, hafıza kaybı, yeni şeyler öğrenme zorluğu ve ani ölümle ortaya çıkabilir. Bilgisayarlı tomografi genellikle iyi tanımlanmış yuvarlak veya oval, kontrast tutmayan bir lezyon gösterir. Kolloid kistlerin manyetik rezonans görüntüleme (MRG) sinyal şiddeti değişkendir ama en sık rastlanan görünüm T1 ağırlıklı dizilerde hiperintens ve T2 ağılıklı dizilerde izo ila hipointenstir. Gözlem, stereotaktik aspirasyon, mikroskopik veya endoskopik yaklaşımlar ve şant cerrahisi çeşitli tedavi seçenekleridir. Transkallosal ve transkortikal mikroskopik (tübüler retraktörle veya olmadan) yaklaşımlar temel olarak sırasıyla normal büyüklükte ve dilate ventriküllerde faydalıdır. Endoskopik teknik, mikrocerrahi tekniğe etkin bir alternatiftir ama total rezeksiyon imkanı ve uzun dönemde nüks olasılığı endişe yaratmaya devam etmektedir. İki alet kullanımı, iki portlu teknik ve tübüler retraktör bazı hastalarda sınırlamaları aşmak açısından faydalı olabilir. Total eksizyon hedeflenmelidir ama subtotal eksizyon ve kalan kist duvarının eksizyonu genellikle kalan duvarda bir büyüme olmadan uzun dönemli iyi sonuçlar verir. Bazı hastalarda açık cerrahiye dönmek de gerekebilir.

ANAHTAR SÖZCÜKLER: Merkezi sinir sistemi kisti, Merkezi sinir sistemi neoplazmı, Kolloid kist, Sinir sistemi hastalıkları, Üçüncü ventrikül

\section{INTRODUCTION}

Colloid cysts are cystic lesions located at the anterior part of third ventricle, close to the foramen of Monro. The cysts are believed to be derived from either primitive neuroepithelium of the tela choroidea or from endoderm. Patients may remain asymptomatic for long time while some can present with paroxysmal headache, gait disturbance, nausea, vomiting, behavioral changes, weaknesses of lower limbs, impaired memory, new learning disability and sudden death. Computed tomography usually reveals a well-defined round or oval nonenhancing lesion. The MRI signal intensity of colloid cysts is notoriously variable, with any combination of T1 and T2 signal intensities. Various management options are available for the treatment of colloid cysts. The two main surgical options are endoscopic resection or microscopic removal by either transcortical or transcallosal approach.
The goals of surgical procedures are to achieve a complete resection avoiding potential long-term recurrence along with CSF pathway restoration with minimal morbidity and mortality.

\section{MATERIAL and METHODS}

This review is based on PubMed and Google search on the subject up to January 2014 and personal experience of surgical management of over 75 colloid cysts by senior author. The aim of this article is to review clinical features, etiology, diagnosis, various management options and complication avoidance in colloid cyst.

\section{Clinical Features}

Patient may remain asymptomatic for very long time and only some patients especially with lesions measuring over 1 
$\mathrm{cm}$ in size may deteriorate $(22,45)$. Colloid cysts can present with paroxysmal headaches and obstructive hydrocephalus. The headache may be brief, severe, worse in the morning and may be exacerbated by leaning the head forward. Other symptoms are gait disturbances, nausea, vomiting, and behavioral changes. Sudden weaknesses in the lower limbs associated with falls without loss of consciousness (drop attacks) has been reported. Impaired memory and new learning ability has been reported. Such tumors may rarely cause death that can occur due to an acute increase of intracranial pressure, neurogenic pulmonary edema and cerebrally triggered cardiac dysfunction (25). Hypothalamic structures, located close to the walls of the third ventricle, and their reflex cardiac effects could explain sudden death when signs of hydrocephalus or brain herniation are lacking (55). Neurogenic stunned myocardium has been observed in such patients with normal coronary arteries seen in angiography (29).

The majority of the patients with a colloid cyst are aged between $30-60$ years.

Although rare in children, (18) such lesions are more aggressive clinical and radiologically.

Familial colloid cysts have been reported in a mother and daughter, and in a sister and brother. It is usually located in the third ventricle but is also reported in lateral ventricle, suprasellar region, frontal, pontomesencephalic area, parietal convexity, and cerebellar region.

The size of these cysts usually varies from 5 to $25 \mathrm{~mm}$ but large cysts are also reported (46). Calcification (46) and hemorrhage, though rare, have been reported in a colloid cyst. These cysts may be associated with suprasellar dermoid, neuroglial heterotopia, and nasal dermoid. Disordered embryogenesis may be related to colloid cyst development. Xanthogranulomas of the third ventricle arising from choroid plexus and other cystic lesions of the third ventricle may mimic colloid cysts.

\section{Etiology}

The origin of these cysts continues to be uncertain. Initial theories favored a neuroepithelial origin from the paraphysis, ependyma, or choroid plexus (42). Some investigators have offered an alternative endodermal source based on morphological analysis (50). Fetal and adult nasal mucosa showing a pattern of immune-histochemical staining almost identical to that of colloid cyst suggest differentiation along nonneural lines (54). Ultrastructural similarities are not observed between colloid cyst and normal or neoplastic neuroepithelium. Ultrastructural findings support the concept of an enterogenous origin of colloid cysts and highlight their similarity to Rathke's cyst (34). The carbohydrate epitopes exhibited by colloid cysts and their contents have also been reported in salivary glands, uterine cervix, gall bladder and colon, and therefore are consistent with the assumption of an endodermal origin of colloid cysts (56).

\section{Diagnosis}

Computed tomography usually reveals the lesion as a homogeneous lesion with two thirds of them appearing hyperdense and one third appearing isodense to the surrounding parenchyma (Figure $1 \mathrm{~A}-\mathrm{I}$ ). The lesions are well delineated and are usually round or ovoid. They are usually nonenhancing and not calcified. Cyst may occasionally have a thin rim of enhancement after contrast injection and may be calcified. Nonenhancement of cyst wall is a reliable discriminator between colloid cyst and Rathke's cyst that shows enhancement. The CT scan is an important preoperative study because the viscosity of the cyst contents correlates more closely than to the density visible on MRI. This viscosity of cyst contents is helpful in determining the most appropriate surgical approach. Most hyperdense cysts on unenhanced CT scans are difficult to aspirate while hypodense cysts are easy to aspirate. Hyperdensity may also correlate with a reduced capacity to enlarge with time. Postoperative CT scan helps in determining any intraventricular hemorrhage, presence or absence of hydrocephalus and the extent of tumor removal (Figure 2A-I).

The MRI signal intensity of colloid cysts is notoriously variable, with any combination of T1- and T2-signal intensities._The most common appearance is hyperintensity in T1-weighted sequences and iso to hypointensity in T2-weighted sequences (Figure 1A-I). This variation is believed to be a result of the proteinaceous fluid, as well as the paramagnetic effects of the metal ions in the fluid and hemorrhage. MRI is valuable in differentiating a colloid cyst from a basilar tip aneurysm and Rathke cleft cyst that may a have similar appearance on a CT scan. The Constructive Interference in the Steady State (CISS) sequence of a MRI can delineate an abnormal contour of the ventricular system and intraventricular septa. Postoperative CISS images can also be used for demonstrating the patency of cyst wall fenestrations. T2 signals can be useful in management planning. The low signal intensity on T2-weighted images have a higher intracystic viscosity contents with an increased difficulty to suck the contents while most high-signal lesions are easy to aspirate. Such lesions are hypointense on diffusion-weighted images while epidermoids have a hyperintense signal.

\section{Management}

Various management options in colloid cysts are observation, stereotactic aspiration, microscopic or endoscopic resection and shunt surgery.

Observation: Patient may remain asymptomatic but some of them may deteriorate. Small asymptomatic lesions of less than $1 \mathrm{~cm}$ without ventriculomegaly may be observed (Figure 3). Spontaneous resolution of colloid cyst has been reported (4). Such patients should be carefully observed by periodical clinical and radiological assessment (45). Although sudden death has been reported, it is less likely in cysts measuring less than $1 \mathrm{~cm}$ diameter (22).

Shunt: Ventriculo-peritoneal shunt draining from single or both the ventricle can be used as a management option 


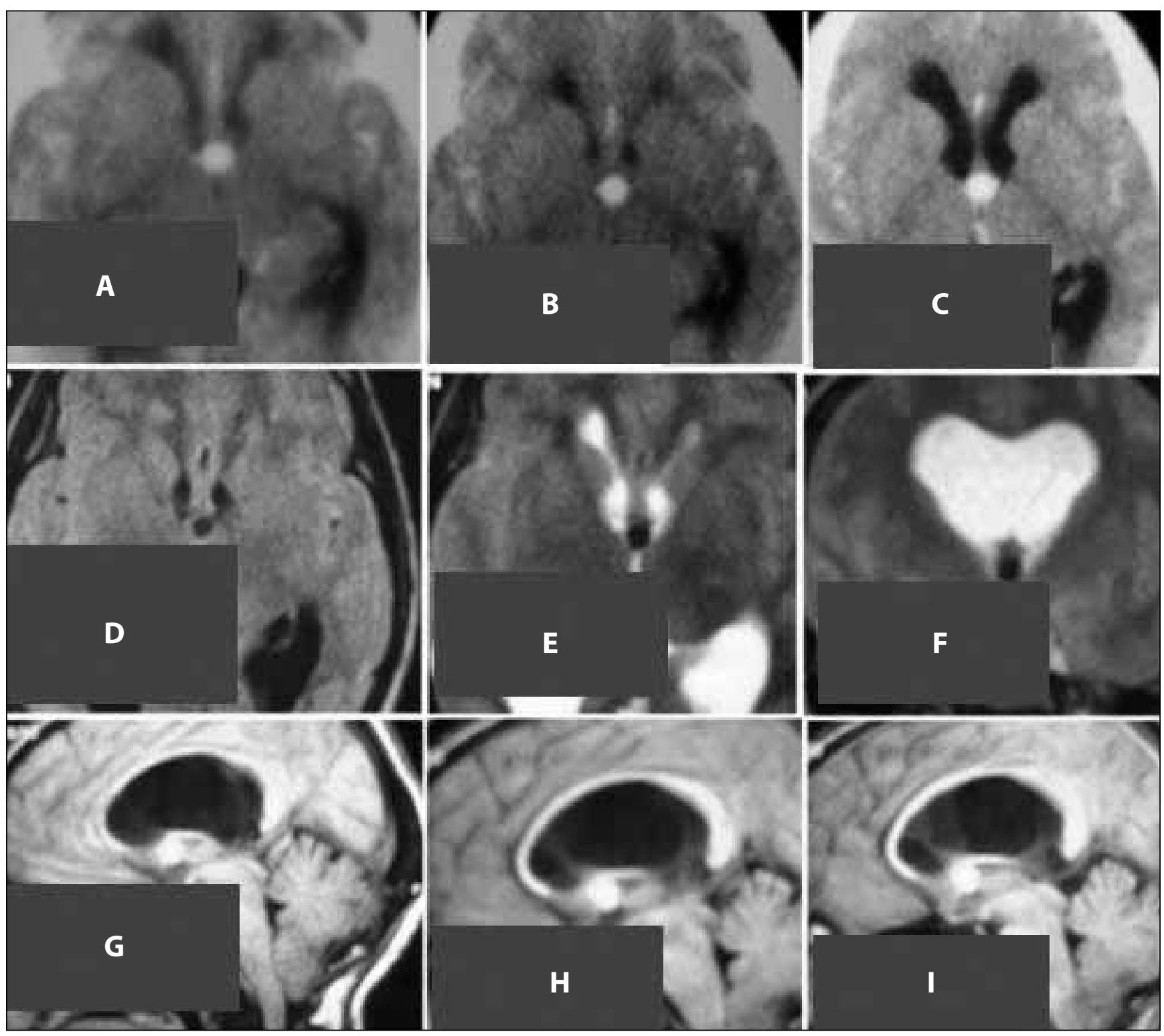

Figure 1: Pre operative CT scan (A-C), MRI scans (D-I) showing third ventricular colloid cyst.

especially in a cyst associated with hydrocephalus in poor surgical risk patient.

Stereotactic treatment: The stereotactic technique can be used when patients are not medically fit. Such techniques are associated with high recurrence rate. Partial cyst wall disruption and aspiration of contents may offer an advantage over simple stereotactic aspiration alone in limiting recurrence (32).

Surgery: Surgical resection should be carried out in cysts measuring over $1 \mathrm{~cm}$ (22). Symptomatic patient, enlarging cyst, or cases with associated hydrocephalus require surgical treatment (45).

Microscopic transcallosal approach: Transcortical or transcallosal approaches are used to remove colloid cysts.
Transcallosal approach is a direct and safe way to treat third ventricular colloid cyst especially when there is no ventriculomegaly (Table I). Favorable outcome with short operative time, good total resection rate associated with minimal morbidity can be achieved by the transcallosal approach (43). The limited anterior callosotomy does not result in disconnection syndromes or behavioral disturbance. Good long-term cognitive performance can be achieved with $1 \mathrm{~cm}$ or less callosal incision along with the meticulous dissection around the fornix in microsurgical approach (47). Results in terms of operative times and postoperative stay can be comparable to endoscopic technique.

Transcavum septum pellucidum interforniceal approach can be used in the presence of cavum septum pellucidum (CSP). Although the interforniceal approach is not routine to reach 


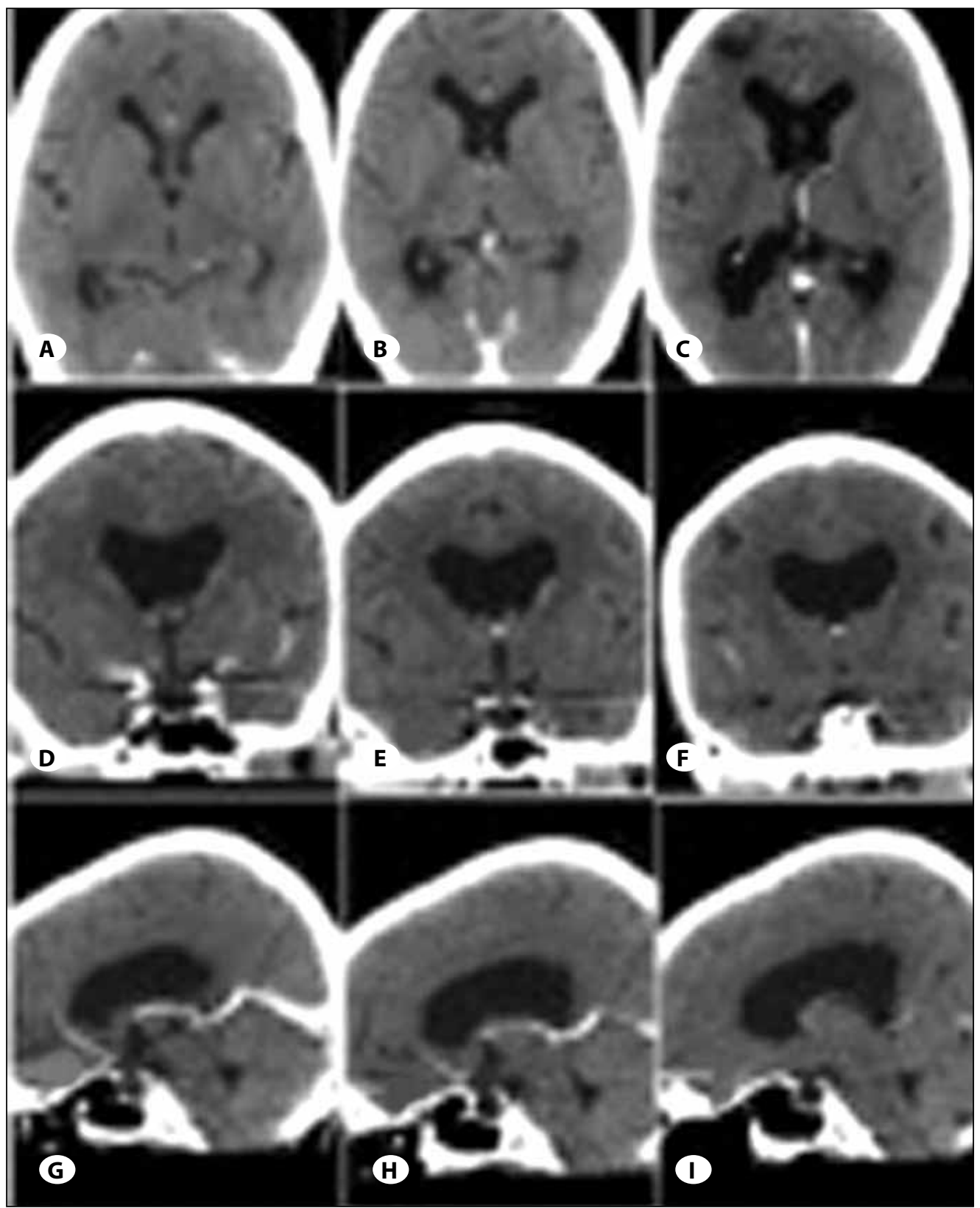

Figure 2: Post - operative CT axial (A-C), coronal (D-F) and sagittal (G - I) images showing near total excision of colloid cyst without any intraventricular bleed.

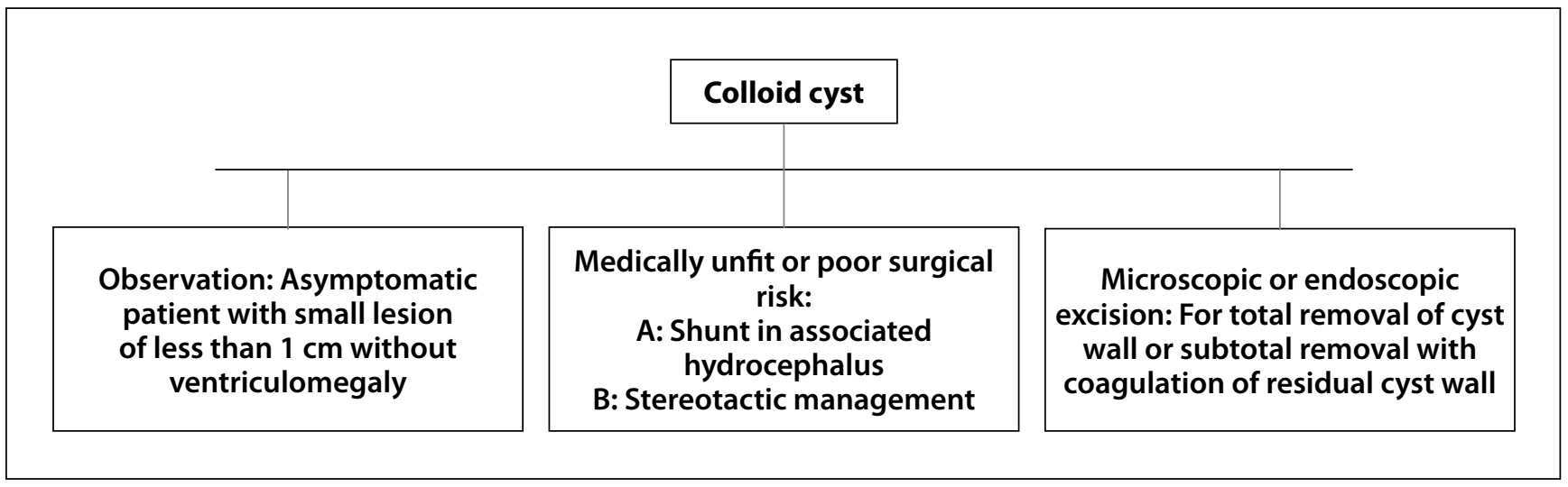

Figure 3: Flowchart of treatment options in colloid cyst. 
Table I: Various Surgical Techniques with Its Advantages and Limitations

\begin{tabular}{|c|c|c|}
\hline Type of surgical procedure & Advantages & Limitations \\
\hline Shunt & $\begin{array}{l}\text { Minimally invasive, can decrease raised } \\
\text { intracranial pressure due to hydrocephalus } \\
\text { in poor surgical risk patient. }\end{array}$ & $\begin{array}{l}\text { Temporary measure, tumor still present, } \\
\text { shunt related problems, pressure on } \\
\text { surrounding structures due to tumor }\end{array}$ \\
\hline Stereotactic treatment & $\begin{array}{l}\text { Minimally invasive, can be used in poor } \\
\text { surgical risk patient. }\end{array}$ & $\begin{array}{l}\text { Only cyst content aspiration or partial cyst } \\
\text { wall disruption increases risk of recurrence }\end{array}$ \\
\hline $\begin{array}{l}\text { Microscopic transcallosal } \\
\text { approach }\end{array}$ & $\begin{array}{l}\text { Can be performed in small ventricles, } \\
\text { greater flexibility to explore entire } \\
\text { anteroposterior extent of third ventricle, no } \\
\text { cortical incision. }\end{array}$ & $\begin{array}{l}\text { Chances of compromising draining vein to } \\
\text { superior sagittal sinus and its consequences, } \\
\text { disconnection syndrome although less } \\
\text { chances if small callosal incision is properly } \\
\text { performed. Cingulate gyrus, pericallosal } \\
\text { artery and fornix injury. }\end{array}$ \\
\hline $\begin{array}{l}\text { Microscopic transcortical } \\
\text { transforaminal resection }\end{array}$ & $\begin{array}{l}\text { Less chances of compromising of draining } \\
\text { vein to sinus, cingulate gyrus injury, and } \\
\text { pericallosal artery damage. }\end{array}$ & $\begin{array}{l}\text { Small ventricle, cortical and fornix injury. } \\
\text { Need for cortical retraction. }\end{array}$ \\
\hline Endoscopic excision & $\begin{array}{l}\text { Minimally invasive with less cortical injury, } \\
\text { no insult to draining veins to sagittal sinus, } \\
\text { no injury to cingulate gyrus or pericallosal } \\
\text { arteries, can be performed in comparatively } \\
\text { less dilated ventricles. }\end{array}$ & $\begin{array}{l}\text { Difficulties in bimanual dissection may } \\
\text { increase problems in control of hemorrhage } \\
\text { and total cyst wall excision, asymptomatic } \\
\text { recurrences may become symptomatic at } \\
\text { long-term follow-up especially in partial cyst } \\
\text { wall excision. }\end{array}$ \\
\hline
\end{tabular}

the third ventricle due to higher risks, it is easier in presence of CSP. Opening of the walls of CSP is recommended to expose both the foramen of Monro and to gain safe access to the third ventricle before manipulating the interforniceal area (53). Acute vasospasm following transcallosal resection of colloid cyst of the third ventricle, though rare, has been observed.

Microscopic transcortical transforaminal resection: Precisely placed small cortical opening with planned trajectory to the foramen of Monro with or without stereotaxy using standard microsurgical instruments can provide safe and effective management of colloid cysts (31). This technique is good when lateral ventricles are dilated. Although this approach can be performed without any tubular retractor (31), a smaller tubular retractor can minimize brain retraction injury (11).

Endoscopic: Endoscopic surgeries are being increasingly used in brain $(16,17,40,49,64)$, spine (60) and skull base lesions $(2,3,7,10)$. Microsurgical technique and the combination of endoscopic visual control offers an effective minimally invasive approach (8).

Procedure: Although endoscopic technique allows better visualization using minimally invasive technique, total resection remains a concern mainly because of lack of bimanual dissection of the cyst wall from the choroid plexus and the vessels (Figure 4A-I). A single instrument is used for dissection most of the time in the endoscopic technique, and the dual instrument technique by passing through the working channels can improve the resection rate.
Tapping the ventricle with a cannula prior to introducing the endoscope is the preferred technique in gaining ventricular access in endoscopic procedures. A soft ventricular catheter instead of a cannula can be passed into the ventricle that can subsequently be used for tracking. The endoscope is introduced along the catheter tract with constant and direct visualization of the shaft of the catheter. The catheter serves as a continuous marker to the ventricle allowing repeated endoscopic entries. This technique can be particularly useful in bi portal procedures (35).

A more anterior approach can be used to better deal with adherences of colloid cyst wall with the tela choroidea, choroid plexus, and the internal cerebral veins (9). Although the anterior approach allows better visualization of the roof of the third ventricle, too anterior an approach places the foramen of Monro in a position that is unsuitable for passage of the rigid scope from the lateral to the third ventricle. A burr hole about 3-5 cm anterior to the coronal suture has been found to be ideal in our experience. Pre operative imaging and help of intra operative navigation is useful in proper planning of the burr hole site (28).

The endoscopic transepto interforniceal approach can be used in colloid cysts of the third ventricle located in a retroforaminal position dissecting the raphe fornix and expanding superoposteriorly in the septum pellucidum (57). Rigid endoscopy affords good optical resolution, high magnification, and excellent illumination. Although illumination of the flexible scope is inferior to the rigid telescope, it allows visualization 
of the attachment of the cyst wall with the roof of the third ventricle and provides the opportunity to widely open the cyst wall and aspirate the cyst fluid under direct visual control (13). A flexible nitinol stone retrieval basket can be used to retrieve a portion of the colloid cyst from any part of the lateral ventricle including the occipital horn (48).

Endoscopic resection of colloid cyst in patients with normal-sized ventricular system may increase the risk of injuring eloquent nervous structures and critical blood vessels because of the limited intraventricular space. The utilization of frameless stereotaxy, tissue shaving device, and ventricular insufflation facilitates the procedure in normal size ventricles (39). There are reports of similar complication rates in endoscopic management of colloid cyst with normal ventricles and those with ventriculomegaly (58).

The dual port endoscopic technique allows excellent visualization of the colloid cyst attachment and permits micro dissection techniques $(5,27,41)$. A tubular retractor under endoscopic visualization allows bimanual dissection in colloid cyst and in other deep-seated cranial lesions (62). It minimizes cortisectomy size, avoids retractor-induced trauma to the overlying brain, can be moved in any direction without

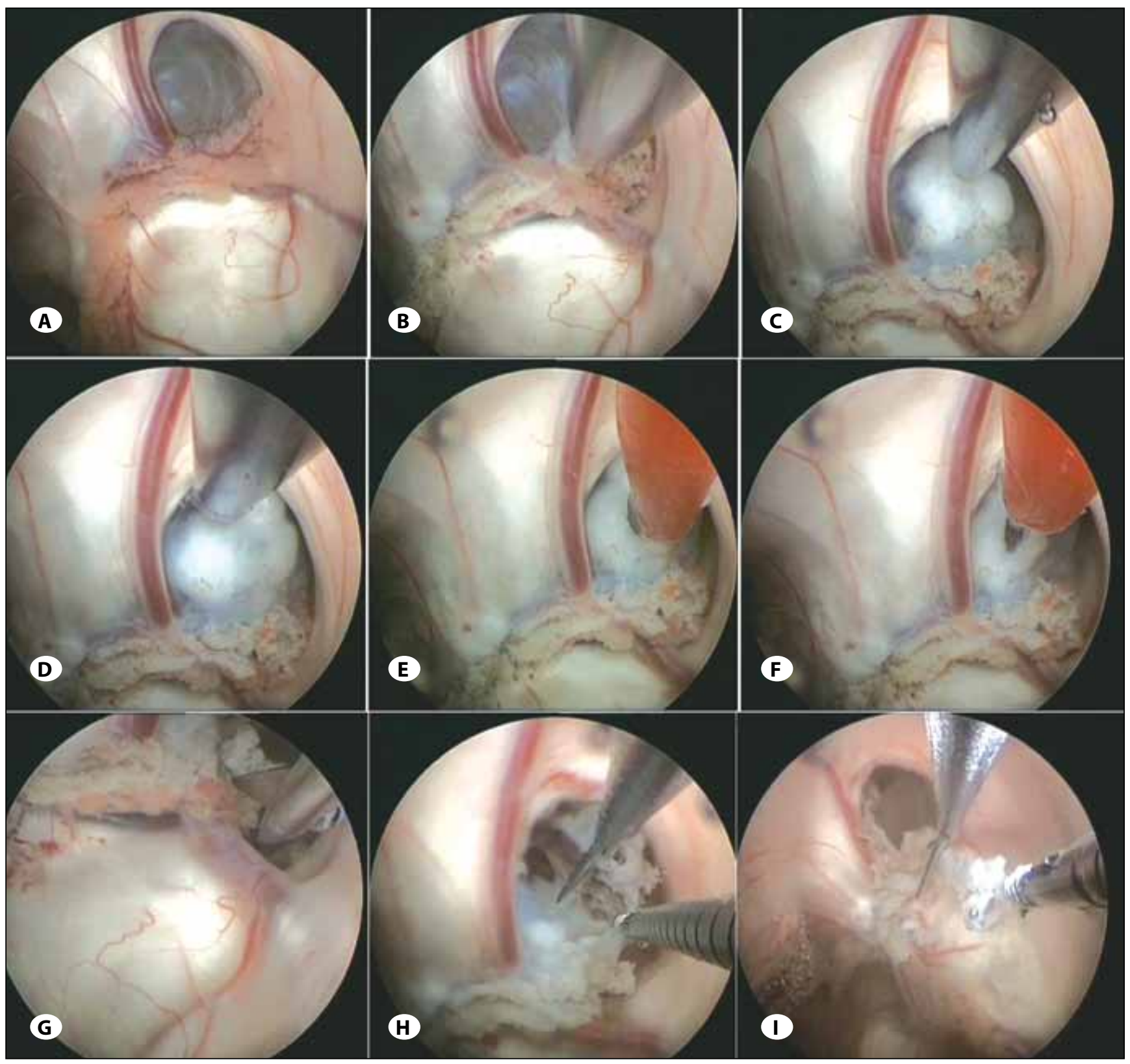

Figure 4: Showing colloid cyst blocking foramen of Monro (A), coagulation of choroid plexus (B) and cyst wall (C, D) and aspiration of cyst contents using catheter (E, F). Cutting of choroid plexus, (G) bimanual dissection and removal of cyst wall using two instruments $(\mathbf{H}, \mathbf{I})$ passed through two separate working channels. 
wastage of time in repositioning of the retractor and does not require any holder (62). There is increased range of viewing angles of the endoscope that facilitates resection of the cyst through a smaller opening. A transparent retractor provides a safer and effective alternative that is not limited by the vascularity, friability, or size of the lesions (15). A Nd:YAG laser can be used for total removal of third ventricle colloid cysts without any increase in morbidity (44).

\section{RESULTS}

Free passage of CSF through the third ventricle can be achieved by reducing the size of the cyst by means of coagulation and suction of the colloid material (20). Continued improvement in endoscopic techniques and instruments, together with good long-term results has established this method as an alternative to microsurgical techniques $(23,26)$. Endoscopic treatment of colloid cysts of the third ventricle is safe and effective (38). It is also an effective alternative to stereotactic aspiration or open craniotomy (1).

Although endoscopic treatment of colloid cysts of the third ventricle is a safe and effective alternative to microsurgical technique, long follow-up will answer the question of tumorfree survival $(38,52)$.

Endoscopy is the first line treatment of the colloid cysts of the third ventricle $(12,30)$. Neuroendoscopic colloid cyst resection can reliably achieve complete removal of tumor with a high level of patient satisfaction (51). There are reports of total reversal of pre operative cardiac dysfunctions after surgery (29). Conversion to an open procedure may be required in some patients $(19,26)$.

The supraorbital approach can be used to obtain a better viewing angle and better control of the adhesion of the cyst to the roof of the third ventricle (14). Endoscopic supracerebellar infratentorial approach can be used when the cyst is associated with a lesion such as an arachnoid cyst in the quadrigeminal cistern (63).

\section{PROGNOSIS}

Symptomatic or asymptomatic recurrences, intraventricular or distant intra parenchymal hemorrhages (21), and fornix injury with anterograde and retrograde amnesia can complicate colloid cyst surgery. The causes of remote brain hemorrhages are obscure; overdrainage of CSF in a short time may contribute to hematoma formation.

The risk of recurrence is minimal with gross total resection and/ or coagulation of the cyst wall (36) while it is high following aspiration of colloid cysts. Asymptomatic recurrences cast a persisting shadow on the long-term results in endoscopic technique (37). It is debatable whether the higher numbers of recurrent or residual cysts can be justified by the slightly lower complication rates of endoscopic removal (6). Although total excision should be aimed, residual cyst wall usually remains asymptomatic without any evidence of growth after subtotal excision and coagulation of wall $(41,61)$. Marsupialization and coagulation of the remaining cyst capsule can result in a long-term recurrence free period (65). Recurrences of colloidal cysts after subtotal and partial removal is infrequent, and the time of the recurrence may be very long or it may not occur at all (33). Colloid cysts in children are more aggressive than their adult counterparts. Immediate postoperative MRI is insufficient for assessing the degree of resection and is a poor predictor of recurrence (24).

\section{COMPLICATIONS and THEIR AVOIDANCE}

\section{Intra-Ventricular Bleeding}

Intra-ventricular bleeding can occur from the ependymal margin of lateral ventricle. Intra-ventricular bleeding can be caused by excessive side movements, removing the flexible scope in curved tip position, wrong entry in the lateral ventricle, injuries due to repeated introduction of endoscope without the use of the peel-away sheath or other sheath, direct ventricular access by the telescope, and the use of a sharp-edged sheath, etc. (59). Rarely blood might trickle from the burr-hole site into the ventricle. Proper hemostasis must be achieved before entering the ventricle. The flexible scope should be removed in a neutral position. If a scope needs to be removed and reintroduced, it is wise to use a peel-away sheath or other sheath in order to maintain the tract without injury to the surrounding structures. Sheaths with a sharp edge should be avoided as it may tear vessels. If the site of entry into the lateral ventricle is wrong, one should not move the scope too much to gain entry into the foramen of Monro. It is better to re-enter at a correct site. Bleeding can occur from the choroid plexus or any vessel while trying to pull the cyst wall without separating its wall from these structures. Both the cyst wall and the tela choroidea should not be pulled. The cyst wall should be properly dissected from other surrounding structures and only the cyst wall should be gently pulled, leaving the tela choroidea. Significant side movement should also be avoided to prevent bleeding due to injuries to the fornix and the veins at the foramen of Monro.

Small hemorrhages during the procedure are usually venous in origin. Copious irrigation with warm lactated Ringer's solution can control most bleeding. The hemorrhage at the site of penetration in the cyst can be stopped by gently keeping any instrument on the bleeding point. If a bleeding site can be identified, cauterization may be attempted. Intermittent careful closure of outflow can also produce a tamponade effect. Maintaining ventricular access is important in severe bleeding. In such cases, the scope must be maintained in the lateral ventricle rather than in the third ventricle, as any movement in the smaller ventricle could be dangerous when there is no proper visualization. The endoscope may be removed but the sheath should be in place. It may take long to stop hemorrhage; once bleeding is stopped, the sheath can be removed after evacuation of intra-ventricular blood. In case of residual oozing, a ventricular drain is recommended. Forceful irrigation may allow visualization of an appropriate site for bipolar coagulation. As a last resort to control bleeding, fluid can be replaced by air and coagulation of the bleeding point can be performed. Fluid should be replaced with air as 
the ventricle would collapse with even worse consequences otherwise. Rapid conversion to open surgery or help of a tubular retractor is recommended when significant bleeding is not controlled by any other technique.

\section{Fornix injury}

A small foramen of Monro can predispose to forniceal injury. The tip of the endoscope can cause fornix injury when the burr-hole is placed too laterally or from the side of the scope when it is moved. Bilateral damage may occur when the contralateral ventricle is entered and the surgeon tries to enter the ipsilateral foramen of Monro. Injury can occur when the flexible scope is removed in the curved tip position. Avoiding ventricular tap by the scope or a large diameter sheath directly can prevent injury. These larger diameter sheaths can injure both fornices if not well-directed. Brain penetration should not exceed $5-6 \mathrm{~cm}$ from the burr-hole and the direction of the sheath should be same as that of the brain needle. If there is an entry into the contralateral ventricle, it is better to abandon that trajectory, remove the scope and re-enter at proper side. Proper planning of the burr-hole, and avoiding significant side movements can avoid forniceal injury and other neural injuries. Use of a small size scope, enlargement of the foramen of Monro by hydro-dissection, and shrinkage of the choroid plexus at the foramen by bipolar coagulation can solve this problem. If the foramen of Monro is small, try to keep the telescope tip in the lateral ventricle as close to the foramen as possible. Rarely the sheath of the telescope can be removed and the scope can be used directly. A flexible scope can be used if the foramen is small and the scope should be in the neutral position at the time of removal to avoid injury.

\section{Subdural Hematoma}

Subdural hematoma, though rare, can develop after faster drainage of a large quantity of CSF from the ventricles, especially when the burr hole is not at the highest point. It can also develop due to separation of brain from the duramater during the introduction of scope for ventricular access without using a brain cannula. Extradural or dural bleeding can trickle in the subdural space. Subdural hematoma can be avoided by preventing rapid drainage of large quantities of CSF. Lost CSF should be replaced with lactated Ringer's solution to prevent brain collapse. Adequate size of cortical incision for the introduction of the scope should be ensured to avoid separation of brain away from the dura. A brain needle should be used rather than direct puncturing of the cortex by the scope to prevent brain separation and subdural hematoma formation. All bleeding points should be controlled before opening the duramater.

\section{CSF Leak}

CSF leak can be due to raised ICP or when there is thin cortical mantle. A large dural or cortical opening can also be responsible for the leak. This leak may stop spontaneously after some time or may persist for a long time. Proper management of raised ICP, small dural opening, and plugging of the cortical margin by absorbable gelatin sponge can avoid CSF leak. Post-operative CSF leak can also be reduced by galeal-pericranial flap.

\section{REFERENCES}

1. Abdou MS, Cohen AR: Endoscopic treatment of colloid cysts of the third ventricle. Technical note and review of the literature. J Neurosurg 89: 1062-1068, 1998

2. Abuzayed B, Tanriöver N, Gazioğlu N, Ozlen F, Eraslan BS, Akar $Z$ : Extended endoscopic endonasal approach to the anterior cranio-vertebral junction: Anatomic study. Turk Neurosurg 19: 249-255, 2009

3. Anik I, Koc K, Cabuk B, Ceylan S: Endoscopic transsphenoidal approach for fibrous dysplasia of clivus, tuberculum sellae and sphenoid sinus; report of three cases. Turk Neurosurg 22: 662-666, 2012

4. Annamalai G, Lindsay KW, Bhattacharya JJ: Spontaneous resolution of a colloid cyst of the third ventricle. Br J Radiol 81(961):e20-22, 2008

5. Bergsneider M: Complete microsurgical resection of colloid cysts with a dual-port endoscopic technique. Neurosurgery 60(2 Suppl 1):ONS33-42, 2007, Discussion ONS42-3

6. Boogaarts HD, Decq $P$, Grotenhuis JA, Le Guérinel C, Nseir $R$, Jarraya $B$, Djindjian $M$, Beems T: Long-term results of the neuroendoscopic management of colloid cysts of the third ventricle: A series of 90 cases. Neurosurgery 68:179-187, 2011

7. Ceylan S, Anik I, Koc K: A new endoscopic surgical classification and invasion criteria for pituitary adenomas involving the cavernous sinus. Turk Neurosurg 21: 330-339, 2011

8. Charalampaki P, Filippi R, Welschehold S, Perneczky A: Endoscope-assisted removal of colloid cysts of the third ventricle. Neurosurg Rev 29: 72-79, 2006

9. Chibbaro S, Champeaux C, Poczos P, Cardarelli M, Di Rocco F, laccarino C, Servadei F, Tigan L, Chaussemy D, George B, Froelich S, Kehrli P, Romano A: Anterior trans-frontal endoscopic management of colloid cyst: An effective, safe, and elegant way of treatment. Case series and technical note from a multicenter prospective study. Neurosurg Rev 37(2):235-241; discussion 241, 2014

10. Chowdhury FH, Haque MR, Kawsar KA, Ara S, Mohammod QD, Sarker $\mathrm{MH}$, Goel AH: Endoscopic endonasal transsphenoidal exposure of circle of Willis (CW); can it be applied in vascular neurosurgery in the near future? A cadaveric study of 26 cases. Turk Neurosurg 22: 68-76, 2012

11. Cohen-Gadol AA: Minitubular transcortical microsurgical approach for gross total resection of third ventricular colloid cysts: Technique and assessment. World Neurosurg 79:207. e7-10, 2013

12. Decq P, Le Guerinel C, Sakka L, Roujeau T, Sol J, Palfi S, Nguyen J: Endoscopic surgery of third ventricle lesions. Neurochirurgie 46: 286-294, 2000

13. Deinsberger W, Böker DK, Samii M: Flexible endoscopes in treatment of colloid cysts of the third ventricle. Minim Invasive Neurosurg 37: 12-16, 1994

14. Delitala A, Brunori A, Russo N: Supraorbital endoscopic approach to colloid cysts. Neurosurgery 69(2 Suppl Operative): ons176-182, 2011 discussion ons182-3 
15. Engh JA, Lunsford LD, Amin DV, Ochalski PG, FernandezMiranda J, Prevedello DM, Kassam AB: Stereotactically guided endoscopic port surgery for intraventricular tumor and colloid cyst resection. Neurosurgery 67(3 Suppl Operative):ons198-204, 2010 discussion ons204-5

16. Ersahin Y: Perioperative complications of intraventricular neuroendoscopy. Turk Neurosurg 20: 423-424, 2010

17. Etus V, Solakoglu S, Ceylan S: Ultrastructural changes in the Liliequist membrane in the hydrocephalic process and its implications for the endoscopic third ventriculostomy procedure. Turk Neurosurg 21: 359-366, 2011

18. Goyal N, Sharma BS, Mahapatra AK: Third ventricular colloid cysts in children-a series of eight cases and review of the literature. Turk Neurosurg 24: 1-7, 2014

19. Greenlee JD, Teo C, Ghahreman A, Kwok B: Purely endoscopic resection of colloid cysts. Neurosurgery 62(3 Suppl 1): 51-55, discussion 55-56, 2008

20. Grunert P, Perneczky A, Resch K: Endoscopic procedures through the foramen interventriculare of Monro under stereotactical conditions. Minim Invasive Neurosurg 37: 2-8, 1994

21. Gurjar H, Dwarakanath S, Sharma BS, Chandra S: Cerebellar hemorrhage following endoscopic third ventricular colloid cyst decompression. Neurol India 56: 218-220, 2008

22. Hamlat A, Pasqualini E, Askar B: Hypothesis about the physiopathology of acute deterioration and sudden death caused by colloid cysts of the third ventricle. Med Hypotheses 63: 1014-1017, 2004

23. Hellwig D, Bauer BL, Schulte M, Gatscher S, Riegel T, Bertalanffy H: Neuroendoscopic treatment for colloid cysts of the third ventricle: The experience of a decade. Neurosurgery 62(6 Suppl 3): 1101-1109, 2008

24. Hoffman CE, Savage NJ, Souweidane MM: The significance of cyst remnants after endoscopic colloid cyst resection: A retrospective clinical case series. Neurosurgery 73:233-237; 2013 discussion 237-239.

25. Hohenstein C, Herdtle S: Unexpected death from a colloid cyst. Int J Emerg Med 27: 65-66, 2010

26. Horn EM, Feiz-Erfan I, Bristol RE, Lekovic GP, Goslar PW, Smith KA, Nakaji P, Spetzler RF: Treatment options for third ventricular colloid cysts: comparison of open microsurgical versus endoscopic resection. Neurosurgery 62(6 Suppl 3): 1076-1083, 2008

27. Horváth Z, Vetö F, Balás I, Dóczi T: Complete removal of colloid cyst via CT-guided stereotactic biportal neuroendoscopy. Acta Neurochir (Wien) 142: 539-545, 2000 discussion 545-546

28. Idris Z, Hallaert G, Vanhauwaert D, Kalala JP, Dewaele F, Baert E, Roost DV, Caemaert J: Frameless neuronavigation-guided endoscopic total en-bloc removal of a third ventricular colloid cyst: A case report on surgical technique. Minim Invasive Neurosurg 51: 173-177, 2008

29. Jarquin-Valdivia AA, Rich AT, Yarbrough JL, Thompson RC: Intraventricular colloid cyst, hydrocephalus and neurogenic stunned myocardium. Clin Neurol Neurosurg 107:361-365, 2005
30. King WA, Ullman JS, Frazee JG, Post KD, Bergsneider M: Endoscopic resection of colloid cysts: Surgical considerations using the rigid endoscope. Neurosurgery 44:1103-1109, 1999 discussion 1109-1111.

31. Kondziolka D, Lunsford LD: Microsurgical resection of colloid cysts using a stereotactic transventricular approach. Surg Neurol 46: 485-490, discussion 490-492, 1996

32. Kumar K, Kelly M, Toth C: Stereotactic cyst wall disruption and aspiration of colloid cysts of the third ventricle. Stereotact Funct Neurosurg 71: 145-152, 1998

33. Kwiek S, Kocur D, Doleżych H, Suszyński K, Szajkowski S, Sordyl R, Slusarczyk W, Kukier W, Bażowski P: Endoscopic technique in the treatment of patients with colloid cysts of the third ventricle. Report based on over a decade of experience. Neurol Neurochir Pol 46: 216-223, 2012

34. Lach B, Scheithauer BW. Colloid cyst of the third ventricle: A comparative ultrastructural study of neuraxis cysts and choroid plexus epithelium. Ultrastruct Pathol 16:331-349, 1992

35. Leonardo J, Hanel RA, Grand W: Endoscopic tracking of a ventricular catheter for entry into the lateral ventricle: Technical note. Minim Invasive Neurosurg 52: 287-289, 2009

36. Levine NB, Miller MN, Crone KR: Endoscopic resection of colloid cysts: Indications, technique, and results during a 13year period. Minim Invasive Neurosurg 50: 313-317, 2007

37. Longatti P, Godano U, Gangemi M, Delitala A, Morace E, Genitori L, Alafaci C, Benvenuti L, Brunori A, Cereda C, Cipri S, Fiorindi A, Giordano F, Mascari C, Oppido PA, Perin A, Tripodi $\mathrm{M}$; Italian Neuroendoscopy Group: Cooperative study by the Italian neuroendoscopy group on the treatment of 61 colloid cysts. Childs Nerv Syst 22: 1263-1267, 2006

38. Longatti $P$, Martinuzzi A, Moro M, Fiorindi A, Carteri A: Endoscopic treatment of colloid cysts of the third ventricle: 9 consecutive cases. Minim Invasive Neurosurg 43:118-123, 2000

39. Margetis K, Souweidane MM: Endoscopic resection of colloid cyst in normal-sized ventricular system. Neurosurg Focus 34(1 Suppl): Video 8, 2013

40. Meybodi AT, Miri SM: Microscopic supraciliary approach for terminal laminotomy for treatment of hydrocephalus: $A$ preliminary report of eight cases. Turk Neurosurg 22: 599-603, 2012

41. Mishra S, Chandra PS, Suri A, Rajender K, Sharma BS, Mahapatra AK: Endoscopic management of third ventricular colloid cysts: Eight years' institutional experience and description of a new technique. Neurol India 58: 412-417, 2010

42. Nagaraju S, O'Donovan DG, Cross J, Fernandes H: Colloid cyst of the third cerebral ventricle with an embryological remnant consistent with paraphysis cerebri in an adult human. Clin Neuropathol 29: 121-126, 2010

43. Pamir MN, Peker S, Ozgen S, Kiliç T, Türe U, Ozek MM: Anterior transcallosal approach to the colloid cysts of the third ventricle: Case series and review of the literature. Zentralbl Neurochir 65:108-115, discussion 116, 2004 
44. Pinto FC, Chavantes MC, Fonoff ET, Teixeira MJ: Treatment of colloid cysts of the third ventricle through neuroendoscopic Nd: YAG laser stereotaxis. Arq Neuropsiquiatr 67:1082-1087, 2009

45. Pollock BE, Huston J 3rd: Natural history of asymptomatic colloid cysts of the third ventricle. J Neurosurg 91: 364-369, 1999

46. Sambasivan M, Padmanabhan S, Sambasivan M: Large colloid cyst of the anterior third ventricle associated with calcification in the cyst wall. Neurol India 58: 330-331, 2010

47. Sampath R, Vannemreddy P, Nanda A: Microsurgical excision of colloid cyst with favorable cognitive outcomes and short operative time and hospital stay: Operative techniques and analyses of outcomes with review of previous studies. Neurosurgery 66: 368-374, discussion 374-375, 2010

48. Schirmer CM, Heilman CB: Complete endoscopic removal of colloid cyst using a nitinol basket retriever. Neurosurg Focus 30: E8, 2011

49. Sharifi G, Alavi E, Rezaee O, Jahanbakhshi A, Faramarzi F: Neuroendoscopic foraminoplasty for bilateral idiopathic occlusion of foramina of Monro. Turk Neurosurg 22:265-268, 2012

50. Shibata T, Burger PC, Kleihues P: Origin of colloid cyst: immunoperoxidase study. No To Shinkei 39: 953-958, 1987

51. Sribnick EA, Dadashev VY, Miller BA, Hawkins S, Hadjipanayis CG: Neuroendoscopic colloid cyst resection: A case cohort with follow-up and patient satisfaction. World Neurosurg 81(3-4):584-593, 2014

52. Teo C: Complete endoscopic removal of colloid cysts: Issues of safety and efficacy. Neurosurg Focus 6: e9, 1999

53. Timurkaynak E, Izci Y, Acar F: Transcavum septum pellucidum interforniceal approach for the colloid cyst of the third ventricle Operative nuance. Surg Neurol 66:544-547, discussion 547, 2006

54. Tsuchida T, Hruban RH, Carson BS, Phillips PC: Colloid cysts of the third ventricle: Immunohistochemical evidence for nonneuroepithelial differentiation. Hum Pathol 23:811-816, 1992
55. Turillazzi E, Bello S, Neri M, Riezzo I, Fineschi V: Colloid cyst of the third ventricle, hypothalamus, and heart: A dangerous link for sudden death. Diagn Pathol 7:144, 2012

56. Veerman EC, Go KG, Molenaar WM, Amerongen AV, Vissink A: On the chemical characterization of colloid cyst contents. Acta Neurochir (Wien) 140: 303-306, discussion 306-307, 1998

57. Vialogo JG: Endoscopic transepto-interforniceal approach to colloid cysts: Case report. Arq Neuropsiquiatr 58: 939-946, 2000

58. Wait SD, Gazzeri R, Wilson DA, Abla AA, Nakaji P, Teo C: Endoscopic colloid cyst resection in the absence of ventriculomegaly. Neurosurgery 73(1 Suppl Operative):ons39-46, 2013 ons46-47.

59. Yadav YR, Parihar V, Kher Y: Complication avoidance and its management in endoscopic neurosurgery. Neurol India 61: 217-225, 2013

60. Yadav YR, Parihar V, Namdev H, Agarwal M, Bhatele PR: Endoscopic inter laminar management of lumbar disc disease. J Neurol Surg A Cent Eur Neurosurg 74: 77-81, 2013

61. Yadav YR, Parihar V, Pande S, Namdev H: Endoscopic management of colloid cysts. J Neurol Surg A Cent Eur Neurosurg 75(5):376-380, 2014

62. Yadav Y R, Yadav Sharda, Sherekar S, Parihar Vijay: A new minimally invasive tubular brain retractor system for surgery of deep brain lesions. Neurology India 59: 74-77, 2011

63. Zanini MA, Rondinelli G, Fernandes AY: Endoscopic supracerebellar infratentorial parapineal approach for third ventricular colloid cyst in a patient with quadrigeminal cistern arachnoid cyst: Case report. Clin Neurol Neurosurg 115: 751-755, 2013

64. Zhu H, Wang Z, Shi W: Keyhole endoscopic hematoma evacuation in patients. Turk Neurosurg 22: 294-299, 2012

65. Zohdi A, El Kheshin S: Endoscopic approach to colloid cysts. Minim Invasive Neurosurg 49: 263-268, 2006 